\title{
Ekologi Lamun di Pulau Sintok, Pulau Kemujan dan Pulau Menjangan Besar Kepulauan Karimunjawa, Jawa Tengah
}

\author{
Abdul Latif Mahakar*, Retno Hartati, Suryono \\ Departemen IImu Kelautan, Fakultas Perikanan dan IImu Kelautan, Universitas Diponegoro \\ JI. Prof.H.Soedarto S.H, Tembalang,Semarang, Jawa Tengah 50275 Indonesia \\ ${ }^{*}$ Corresponding author, e-mail : latif10mahakar@gmail.com
}

\begin{abstract}
ABSTRAK : Lamun memiliki tingkat produktivitas primer yang tinggi dan memiliki kemampuan dalam meredam kekuatan arus dan gelombang. Membuat ekosistem lamun sangat menarik dan nyaman bagi kehidupan organisme perairan, baik sebagai tempat untuk mencari makan, tempat memijah ataupun tempat untuk pembesaran anak/larva/juvenile. Padang lamun merupakan ekosistem yang bermanfaat, tetapi kurang diperhatikan. Peneltian ini bertujuan Mengidentifikasi jenis, mengetahui kerapatan dan tutupan lamun di perairan Pulau Sintok, Pulau Kemujan dan Pulau Menjangan Besar Kepulauan karimunjawa. Metode yang digunakan dalam penelitian adalah metode survey. Pengamatan sampel lamun dilakukan dengan metode transek kuadran dan penentuan lokasi penelitian mengguanakan metode purposive sampling, dibagi berdasarkan zonasi. Analisis data berupa perhitungan kerapatan ( $\left.\mathrm{Ind} / \mathrm{m}^{2}\right)$ dan penutupan lamun (\%). Hasil penelitian telah menemukan 6 jenis lamun, yaitu Cymodocea serrulata, Cymodocea rotundata, Enhalus acoroides, Thalasia hemprichi, Halophila ovalis dan Halophila minor. Pulau Sintok sebagai zona perlindungan bahari memiliki nilai kerapatan lamun tertinggi dengan kisaran 98,22$5,56 \mathrm{Ind} / \mathrm{m}^{2}$. Diikuti oleh Pulau Menjangan Besar dengan kisaran 62,67-12,67 Ind/m sebagai zona pemanfaatan wisata bahari dan Pulau Kemujan sebagai zona pemukiman dengan kisaran 50$27,33 \mathrm{Ind} / \mathrm{m}^{2}$. Sedangkan untuk tutupan lamun, pada Pulau Sintok dengan kisaran $23,61-1,30 \%$. Pulau Kemujan dengan kisaran 22,61-10,29\% dan Pulau Menjangan Besar berkisar 18,75-2,39\%. Thalasia hemprichi adalah spesies dengan nilai kerapatan dan tutupan tertinggi dari seluruh lokasi penelitian dengan $98,22 \mathrm{Ind} / \mathrm{m}^{2}$ dan $23,61 \%$. Dan spesies terendah untuk kerapatan dan tutupan adalah Cymodocea serrulata dengan 5,56 Ind $/ \mathrm{m}^{2}$ dan 1,30\%.
\end{abstract}

Kata Kunci : Jenis, Kerapatan, Tutupan, Lamun, Zonasi, Karimunjawa

\section{Ecology Seaweed on Sintok Island, Kemujan Island and Menjangan Besar Island of Karimunjawa Islands, Central Java}

\begin{abstract}
Seagrass have primary level of productivity is high and has the ability to soften the strength of the current and waves. Make seagrass ecosystem is very interesting and comfortable for the life of the organism the waters, both as a place to feeding ground, spawning ground or place to nursery ground. The seagrass is a useful ecosystem, but less noted. This research aims identify the species, know the density and seagrass cover at Sintok Island, Kemujan Island and Menjangan Besar Island Karimunjawa Islands. This research conducted on 15 May 2016 at Sintok Island, Kemujan Island and Menjangan Besar Island Karimunjawa Islands. The method used in this research is the survey method. Sample observation seagrass done with the transect quadrant method. The determination of the location of the research using the method purposive sampling, divided based on over zoning. Data Analysis in the form of calculating the density $\left(\mathrm{Ind} / \mathrm{m}^{2}\right)$ and seagrass cover (\%). The results of research has found 6 species of seagrass, namely, Cymodocea rotundata Cymodocea serrulata, Enhalus acoroides, Thalasia hemprichi, Halophila ovalis and Halophila minor. Sintok island as protection zone bahari has the highest seagrass density value with a range of 98,22-5.56 Ind/ $\mathrm{m}^{2}$. Followed by of Menjangan Besar Island with $62,67-12,67 \mathrm{Ind} / \mathrm{m}^{2}$ as a zone of the utilization of marine tourism and Kemujan Island as residential zone with a range of 50-27,33 Ind $/ \mathrm{m}^{2}$. While for the seagrass cover,on the Sintok Island with a range of $23,61-1,30 \%$. Kemujan Island with a range of 22,61-10,29\% and And Menjangan Besar Island range 18,752.39\%. Thalasia hemprichi is the species with the value of the density and the highest cover from the entire research location with $98,22 \mathrm{Ind} / \mathrm{m}^{2}$ and $23,61 \%$. And the species to low density and cover is Cymodocea serrulata with $5.56 \mathrm{Ind} / \mathrm{m}^{2}$ and $1,30 \%$.
\end{abstract}

Keywords : Species, Density, Cover, Seagrass, Zone, Karimunjawa 


\section{PENDAHULUAN}

Padang lamun merupakan ekosistem yang sangat penting dalam menjaga keseimbangan ekosistem di perairan (Dahuri, 2001). Tingginya produktivitas primer di daerah padang lamun dan kemampuannya dalam meredam kekuatan arus dan gelombang membuat kawasan ini sangat menarik dan nyaman bagi kehidupan organisme perairan, baik sebagai tempat untuk mencari makan (feeding ground), tempat memijah (spawning ground) ataupun tempat untuk pembesaran anak/larva/juvenil (nursery ground). Padang lamun merupakan ekosistem yang bermanfaat, tetapi di Indonesia pemanfaatannya untuk kebutuhan manusia kurang di optimalisasikan, bahkan cenderung dirusak karena kepentingan yang lain. Beberapa faktor yang mempengaruhi kerusakan padang lamun antara lain pencemaran limbah industri, limbah pertanian, pembuangan sampah organik cair, pengerukan pasir dan reklamasi pantai serta pembatasan secara langsung (Dahuri, 2001).

Ekosistem lamun sampai saat ini masih kurang mendapat perhatian (Bengen, 2000). Hal ini dikarenakan kurangnya pengetahuan masyarakat tentang fungsi ekosistem lamun dan dikarenakan masyarakat belum dapat mengambil manfaat langsung dari lamun. Akibatnya, upaya masyarakat dalam menjaga kelestarian ekosistem ini sangat minim bahkan terkadang dianggap sebagai tanaman pengganggu, sehingga akhirnya diabaikan atau dimusnahkan (Hartati et al.,2012). Padahal lamun memiliki beberapa manfaat dan peranan penting di dalam perairan. Seperti sebagai produsen primer, sebagai habitat biota, sebagai penangkap sedimen dan sebagai pendaur zat hara. (Phillips \& Menez, 1988).

Balai Taman Nasional (BTN) Karimunjawa telah menentukan zonasi pada wilayah perairan dan pulau di Kepulauan Karimunjawa. berdasarkan Keputusan Direktur Jenderal Perlindungan Hutan Dan Konservasi Alam No: SK. 28/IV-SET/2012 Tentang Zonasi Taman Nasional Karimunjawa tanggal 06 Maret 2012. Didalam peraturan tersebut Pulau Sintok termasuk dalam zona perlindungan bahari, Pulau Kemujan zona budidaya dan zona pemukiman dan Pulau Menjangan Besar zona pemanfaatan wisata bahari. Fungsi dari ekosistem lamun yang sangat penting bagi perairan perlu dilakukan suatu penelitian untuk mengetahui kondisi ekosistem lamun di perairan Kepulauan Karimunjawa yang dimana telah diberlakukan zonasi terhadap beberapa pulau disana, diantaranya adalah Pulau Sintok, Pulau Kemujam dan Pulau Menjangan Besar. Apakah pemberlakuan zonasi tersebut cukup berpengaruh terhadap pertumbuhan lamun.

Penelitian ini bertujuan untuk mengidentifikasi jenis lamun, mengetahui kerapatan dan tutupan lamun di Perairan Pulau Sintok, Pulau Kemujan dan Pulau Menjangan Besar Kepulauan karimunjawa.

\section{MATERI DAN METODE}

Penelitian ini dilakukan di Pulau Sintok, Pulau Kemujan dan Pulau Menjangan Besar, Kepulauan Karimunjawa. Metode penelitian yang digunakan yaitu deskriptif eksploratif. Penentuan lokasi penelitian menggunakan metode purposive sampling dimana penentuan/pengambilan sampel dengan sengaja dan berdasarkan suatu pertimbangan dan tujuan tertentu (Sugiyono, 2010). Dan penentuannya berdasarkan zonasi di wilayah Perairan Karimunjawa sesuai Keputusan Direktur Jenderal Perlindungan Hutan Dan Konservasi Alam No: SK. 28/IV-SET/2012 Tentang Zonasi Taman Nasional Karimunjawa tanggal 06 Maret 2012.

Metode pendataan lamun menggunakan metode line transect quadran. Transek kuadran dibentang tegak lurus terhadap garis pantai, dimulai dari titik 0 (nol) pada meteran. Penentuan titik 0 (nol) dimulai dari ditemukannya jenis lamun pertama, kemudian ditarik garis kearah laut lepas sepanjang $50 \mathrm{~m}$. Satu stasiun terdapat 3 (tiga) garis transek, dengan jarak antar garis transek kesamping adalah $50 \mathrm{~m}$. Jarak transek dalam satu garis transek adalah $25 \mathrm{~m}$. Total transek dalam satu stasiun adalah 9 (sembilan) transek.

Pengamatan lamun meliputi jenis, kerapatan, dan persentase tutupan lamun. Pengamatan lamun dilakukan dengan cara menempatkan transek kuadran dengan ukuran $1 \mathrm{~m} \times 1 \mathrm{~m}$ yang dimodifikasi menjadi 16 sub plot berukuran $25 \mathrm{~cm}$. identifikasi jenis lamun menggunakan buku indentifikasi lamun seagrasswatch, (McKenzie et al., 2003). Pengamatan parameter kualitas air di ukur secara in-situ bersaman dengan pendataan lamun. Parameter yang diamati meliputi suhu, 
salinitas, $\mathrm{pH}$, kedalaman, dan kecerahan.

Rumus yang digunakan untuk menghitung kerapatan lamun seperti yang ditunjukkan oleh persamaan sebagai berikut:

$$
\mathrm{Di}=\frac{N i}{A}
$$

Keterangan : Di : Kerapatan jenis (tegakan $/ \mathrm{m}^{2}$ ); $\mathrm{Ni}$ : Jumlah total individu dari jenis I (tegakan); A : Luas area total pengambilan contoh $\left(\mathrm{m}^{2}\right)$

Tutupan lamun digunakan metode saito dan adobe (Kepmen LH, 2004) :

$$
\mathrm{C}=\frac{\sum(\mathrm{Mi} \times \mathrm{fi})}{\sum \mathrm{f}}
$$

Keterangan : C : Luas penutupan lamun (\%); Mi : Nilai tengah persentase kelas-I; fi : Frekuensi jenis I; $f$ : Frekuensi (transek)

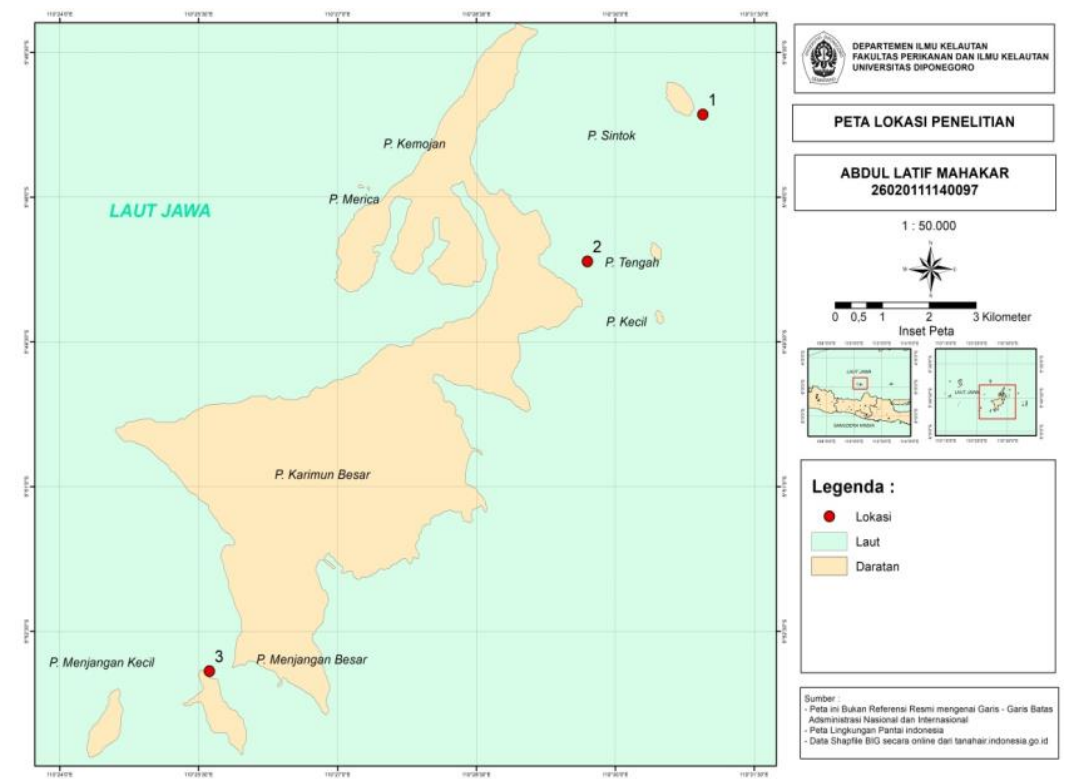

Gambar 1. Peta Lokasi Penelitian

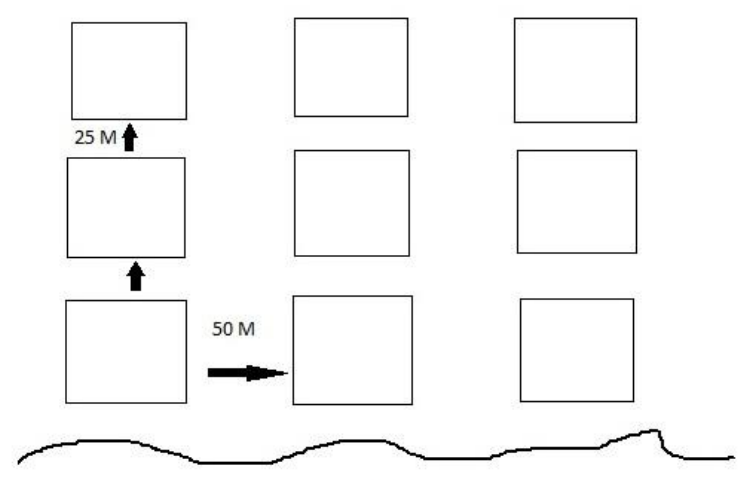

Garis Pantai

Gambar 2. Layout transek kuadran di lokasi penelitian

\section{HASIL DAN PEMBAHASAN}

Hasil identifikasi dari jenis lamun yang dilakukan di perairan Pulau Sintok, Pulau Kemujan dan Pulau Menjangan Besar terdapat 6 jenis lamun. Diantaranya $E$. acoroides, T. hemprichii, H. ovalis, $H$. minor, $C$. rotundata, $C$. Serrulata. Dimana spesies yang paling sering ditemukan di semua lokasi penelitia adalah $T$. hemprichii. Kemudian spesies ini adalah dengan tingkat kerapatan tertinggi yaitu 
98,22 Individu $/ \mathrm{m}^{2}$ dan presentase tutupan paling tinggi dengan $23,61 \%$. Dimana hasil ini serupa dengan peneltian yang dilakukan oleh Hartati et al. (2012) di perairan Kepulauan Karimunjawa tepatnya di Pulau Kumbang yang juga menemukan 6 spesies lamun, yang juga $T$. hemprichii menjadi spesies dengan nilai kerapatan tertinggi dengan 77.11 Individu/ $\mathrm{m}^{2}$. Hal ini diperkuat oleh pernyataan Tomascik et al. (1997), jenis T. hemprichii sering ditemukan melimpah pada daerah yang memiliki substrat dasar pasir lanau, pasir kasar, dan pecahan karang karena secara morfologi jenis ini memiliki rimpang yang tebal dan kokoh sehingga memungkinkan untuk tumbuh pada substrat yang bervariasi.

Hasil perhitungan kerapatan lamun menunjukan bahwa Pulau Sintok adalah lokasi dengan nilai kerapatan lamun tertinggi. Telah ditemukan 5 spesies lamun yaitu $T$. hemprichii $(98,22$ Individu $/ \mathrm{m}^{2}$ ) adalah spesies yang paling tinggi nilai kerapatannya kemudian diikuti dengan $C$. rotundata $\left(76,89\right.$ Individu/m²), $H$. ovalis $\left(31,56\right.$ Individu $\left./ \mathrm{m}^{2}\right), H$. minor $(24,89$ Individu/m²) dan $C$. serrulata (5,56 Individu/m²). Faktor yang mempengaruhi kondisi lamun pada suatu perairan diantaranya adalah kedalaman. Di lokasi ini lamun ditemukan pada perairan dangkal dimana suatu perairan dangkal biasanya memiliki variasi habitat yang lebih besar dibandingkan bagian yang lebih dalam sehingga cenderung memiliki lamun yang lebih tinggi keanekaragamannya. Kemudian Analisa sedimen pada lokasi ini yaitu sand $97,4 \%$, silt 2,1\%, clay 0,53 \%, Pulau Sintok merupakan lokasi dengan substrat dominasi pasir paling tinggi diantara lokasi lainnya. Dimana hal ini mempengaruhi tingkat kerapatan lamun, semakin kecil ukuran sedimen maka semakin tinggi kerapatan lamun. kandungan bahan organik di lokasi ini sebesar 5,63\% yang juga tertinggi diantara lokasi lain, hal ini juga berpengaruh terhadap kerapatan lamun dimana Sofiana et al.,(2016) menemukan hasil yang menyebutkan bahwa kandungan bahan organik yang tinggi ditemukan pada kerapatan lamun yang tinggi pula. Selain dari faktor-faktor tersebut, tingkat kerapatan lamun diduga dipengaruhi juga oleh status Pulau Sintok sebagai zona perlindungan bahari (Keputusan Direktur Jenderal Perlindungan Hutan Dan Konservasi Alam No: SK. 28/IV-SET/2012 Tentang Zonasi Taman Nasional Karimunjawa, 2012). Hasil ini serupa dengan hasil penelitian yang dilakukan oleh Nugraha dan Rudi (2012) di kawasan perairan Pulau Parang yang dimana mendapati kerapatan lamun tertinggi terdapat di Pulau Kembar dengan jenis yang memiliki nilai kerapatan tertinggi yaitu T. hemprichii (167 ind/m2). Status Pulau Kembar sama dengan Pulau Sintok, yaitu termasuk dalam zona perlindungan bahari.

Pulau Kemujan adalah lokasi dengan nilai kerapatan terendah dari dua pulau lainnya. Di lokasi ini telah ditemukan 4 spesies lamun dengan nilai kerapatan tertinggi yaitu spesies $T$. hemprichii $\left(50,00\right.$ Individu $\left./ \mathrm{m}^{2}\right)$, C. serrulata $\left(28,00\right.$ Individu $\left./ \mathrm{m}^{2}\right)$, H. minor $\left(23,56\right.$ Individu $\left./ \mathrm{m}^{2}\right)$ dan yang terendah adalah $E$. acoroides $\left(20,73\right.$ Individu/ $\left.\mathrm{m}^{2}\right)$. Hasil analisa sedimen untuk stasiun 4 adalah sand $87,6 \%$, silt $9,9 \%$, clay $2,5 \%$. Kompoisi sedimen merupakan faktor yang berpengaruh pada kerapatan lamun, adanya perbedaan komposisi jenis substrat dapat menyebabkan perbedaan komposisi jenis lamun dan juga dapat mempengaruhi perbedaan kesuburan dan pertumbuhan lamun. Hal ini didasari oleh pemikiran bahwa perbedaan komposisi ukuran butiran pasir akan menyebabkan perbedaan nutrisi bagi pertumbuhan lamun, proses dekomposisi dan meneralisasi yang terjadi di dalam substrat. Kemudian dengan kandungan bahan organik yang terendah juga sebesar 4,2\%. Kemudian kedalaman pada saat lamun ditemukan pada lokasi ini adalah $150 \mathrm{~cm}$ dimana lokasi ini paling tinggi kedalamannya diantara lokasi lain.

Tabel 1. Jenis Lamun di Lokasi Penelitian

\begin{tabular}{llccc}
\hline No & Jenis lamun & P. Sintok & P. Kemujan & P.Menjangan Besar \\
\hline 1 & Enhalus acoroides & - & + & - \\
2 & Thalasia hemprichii & + & + & + \\
3 & Cymodocea rotundata & + & - & + \\
4 & Cymodocea serrulata & + & + & + \\
5 & Halophila minor & + & + & + \\
6 & Halophila ovalis & + & - & 5 \\
\hline \multicolumn{2}{c}{ (Catatan : + : ada; - : tidak ada) } & 5 & 4 & \\
\hline
\end{tabular}


Hal ini juga berpengaruh di mana kedalaman sangat mempengaruhi kehidupan tumbuhan perairan. Selain Faktor-faktor diatas faktor lainnya yang diduga mempengaruhi tingkat kerapatan lamun yaitu status Pulau Kemujan sebagai zona pemukiman (Keputusan Direktur Jenderal Perlindungan Hutan Dan Konservasi Alam No: SK. 28/IV-SET/2012 Tentang Zonasi Taman Nasional Karimunjawa, 2012). Pulau berpenghuni yang dimana ada aktifitas masyarakat disitu yang mungkin mempengaruhi tingkat kerapatan lamun disitu yang bisa disebabkan oleh limbah masyarakat setempat. Yang dimana pembuangan sampah adalah salah satu faktor yang telah telah diketahui selain pembangkit tenaga listrik, sedimentasi dan energi angin yang merupakan faktor-faktor yang dapat mempengaruhi pertumbuhan lamun disuatu daerah perairan (Hartati et al., 2012). Sedangkan penelitian yang dilakukan oleh Hartati et al., (2017) di Pulau Karimunjawa. Menemukan 6 jenis lamun yaitu $C$. rotundata, $C$. serrulata, T. hemprichii, $E$. acoroides, $H$. ovata dan $H$. pinifolia. Dengan $T$. hemprichii dan $E$. acoroides spesies yang memiliki nilai tutupan tertinggi (42.2 and $30.8 \%$ ). Hal ini disebabkan oleh kandungan bahan organik pada lokasi inilebih tinggi. Jumlah penduduk dan aktifitas manusia disini lokasi ini juga lebih tinggi karena Pulau Karimunjawa juga merupakan termasuk dalam zona pemukiman sama seperti Pulau Kemujan.

Di Pulau Menjangan Besar spesies dengan nilai kerapatan tertinggi yaitu $H$. minor $(62,67$ Individu $\left./ \mathrm{m}^{2}\right)$, diikuti dengan $H$. ovalis $\left(50,89\right.$ Individu $\left./ \mathrm{m}^{2}\right) \quad$ C. serrulata $\left(26,22\right.$ Individu $\left./ \mathrm{m}^{2}\right), T$. hemprichii $\left(13,33\right.$ Individu $\left./ \mathrm{m}^{2}\right)$ dan yang terendah adalah $C$. rotundata $\left(12,67\right.$ Individu $\left./ \mathrm{m}^{2}\right)$. Dari hasil analisa sedimen untuk lokasi Pulau Menjangan Besar adalah sand 90,6 \%, silt 6,9 \%, clay 2,5\%. Lokasi ini adalah dengan komposisi substrat berpasir tertinggi kedua dari lokasi lainnya. sedangkan kandungan bahan organiknya juga kedua tertinggi dari lokasi lainnya sebesar 4,36 \%. Lokasi ini juga memiliki kedalaman terendah kedua dari ketiga lokasi lainnya. Kesemua hal ini berkolerasi dengan status tingkat kerapatan lamun di Pulau Menjangan Besar tertinggi kedua dari kedua pulau lainnya, dimana menurut menurut Tomascik (1977)

Tingginya kandungan bahan organik dalam substrat sangat menunjang proses pertumbuhan dari lamun dan Perbedaan komposisi jenis substrat dapat menyebabkan perbedaan komposisi jenis lamun dan juga dapat mempengaruhi perbedaan kesuburan dan pertumbuhan lamun. Faktor lain penyebab tingkat kerapatan lamun pada lokasi ini bisa diduga yaitu status dari lokasi Pulau Menjangan Besar yaitu zona pemanfaatan wisata bahari. Banyaknya kegiatan wisata oleh manusia pada Pulau Menjangan Besar bisa diduga menjadi salah satu faktor yang mempengaruhi kerapatan lamun pada lokasi ini. Tidak seperti ekosistem terumbu karang, rumput laut dan mangrove, ekosistem lamun sampai saat ini masih kurang mendapat perhatian (Bengen, 2000). Tingginya minat masyarakat terhadap pariwisata di Kepulauan Karimunjawa, akan tetapi sangat disayangkan dengan tidak disertainya pengetahuan tentang fungsi ekosistem lamun. Akibatnya, upaya masyarakat dalam menjaga kelestarian ekosistem ini sangat minim bahkan terkadang dianggap sebagai tanaman pengganggu, sehingga akhirnya diabaikan atau dimusnahkan (Hartati et al., 2012). Seperti ketika sedang melakukan kegiatan snorkling dan bermain di perairan dangkal para wisatawan masih banyak yang menginjak-nginjak lamun karna belum tahu apa itu lamun dan

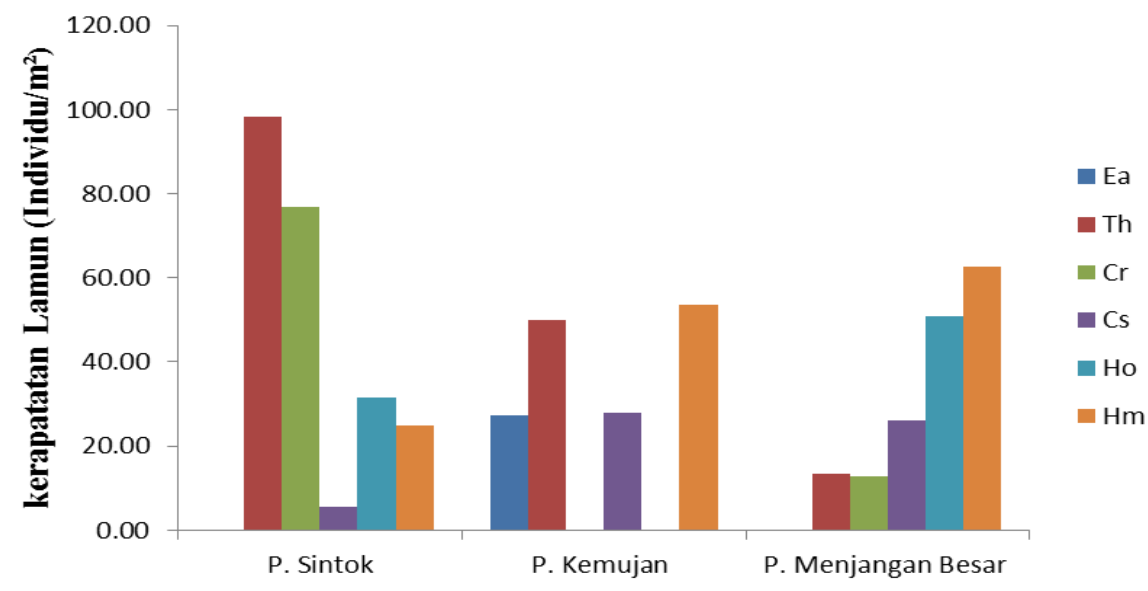

Gambar 3. Kerapatan lamun pada lokasi penelitian (Individu/m²). 
fungsinya. Sementara hasil dari peneltian yang dilakukan oleh Hartati et al.,(2012) di Pulau Kumbang yang juga termasuk pada zona pemanfaatan wisata bahari telah ditemukan 6 jenis lamun dengan $T$. hemprichii adalah spesies dengan nilai kerapatan tertinggi dengan 77.11 Individu $/ \mathrm{m}^{2}$. Pulau Kumbang merupakan termasuk dalam zona pemanfaatan wisata bahari sama seperti dengan Pulau Menjangan Besar, akan tetapi jumlah jenis lamun yang ditemukan sedikit lebih banyak pada Pulau Kumbang. Hal ini mungkin dipengaruhi oleh kurang diminatinya Pulau Kumbang oleh para wisatawan dibanding dengan Pulau Menjangan Besar. Wisatawan lebih tertarik mengunjungi Pulau Menjangan Besar biasanya disebabkan karena adanya penangkaran hiu yang sangat menarik perhatian para wisatawan.

Di Pulau Sintok dapat dilihat dari hasil yang perhitungan tutupan lamun menunjukan bahwa spesies T. hemprichii $(23,61 \%)$ adalah spesies yang paling tinggi presentase tutupannya. Kemudian diikuti dengan $C$. rotundata $(14,97 \%), H$. ovalis $(5,95 \%) H$. minor $(5,17 \%)$ dan presentase tutupan yang rendah yaitu $C$. serrulata $(1,30)$. Pada Pulau Kemujan spesies lamun dengan presentase tutupan tertinggi yaitu $H$. minor (22,61\%), kemudian diikuti $T$. hemprichii $(21,27 \%)$, C. serrulata (10,46\%), dan yang terendah adalah E. acoroides (10,29). Kemudian pada Pulau Menjangan Besar spesies dengan presentase penutupan tertinggi yaitu $H$. minor $(18,75 \%)$, diikuti dengan $H$. ovalis $(9,38 \%)$, C. serrulata $(3,64 \%)$, T. hemprichii $(3,60 \%)$ dan yang terendah adalah C.a rotundata (2,39\%).

Romimoharto dan Juwana (2001), mengatakan bahwa semakin tinggi nilai kerapatan lamun, maka presentase penutupanya juga relatif makin tinggi. Hal ini terbukti dengan hasil yang didapatkan, pada spesies $T$. hemprichii adalah spesies dengan nilai kerapatan dan tutupan tertinggi dari semua lokasi penelitian. Kemudian diikuti oleh spesies $H$. minor yang kerapatan dan tutupannya tertinggi pada Pulau Kemujan dan Pulau Menjangan Besar. $H$. minor juga menjadi spesies dengan tingkat kerapatan dan tutupan tertinggi kedua pada semua lokasi penelitian.

Selain komposisi substrat dan kedalaman bisa dilihat bahwa faktor zonasi pada wilayah perairan Kepulauan Karimunjawa juga sangat mempengaruhi pertumbuhan lamun. Seperti yang sudah diketahui bahwa Pulau Sintok yang berstatus zona perlindungan bahari memiliki nilai kerapatan lamun tertinggi yang diikuti oleh Pulau Menjangan Besar yang berstatus zona wisata bahari dan Pulau Kemujan yang berstatus zona pemukiman. Hasil yang serupa juga didapatkan oleh Feryatun et al., (2012) yang dimana telah melakukan penelitian berdasarkan zonasi di Perairan Pulau Pramuka. Yang dimana telah ditemukan 7 jenis lamun, yaitu $C$. rotundata, $C$. serrulata, E. acoroides, $H$. uninervis, $H$. ovalis, T. hemprichii dan S. isoetifolium.

Berdasarkan hasil penelitian yang dilakukan, di ketiga stasiun pengamatan jumlah dan jenis lamun yang ditemukan berbeda (tidak selalu sama), yakni jenis terbanyak ditemui pada stasiun 1 (zona alami) sebanyak tujuh jenis, sedangkan pada stasiun 2 (zona pemukiman) dan 3 (zona resort wisatawan) hanya dijumpai empat jenis lamun. Nilai kerapatan jenis tertinggi juga terdapat di stasiun 1 yakni 1.620 individu/15m2. Stasiun 1 (zona alami) kondisi lingkungannya masih alami dalam kondisi baik dan belum tercemar oleh aktivitas masyarakat maupun aktivitas wisata sehingga diduga lamun tumbuh baik disana, sedangkan pada stasiun 2 dan 3 (zona pemukiman dan resort) kondisi lingkungannya sudah dipengaruhi oleh berbagai kegiatan manusia (seperti adanya limbah/sampah, kegiatan nelayan setempat maupun untuk pariwisata) yang menjadikan kondisi perairan dan lingkungan sedikit terganggu sehingga mempengaruhi ekosistem lamun yang ada disana. Penelitian ini juga mendapatkan Jenis yang mendominasi di ketiga stasiun adalah $T$. hemprichii.

Kondisi lingkungan perairan mempengaruhi kehidupan biota yang ada dilingkungan tersebut baik secara langsung atau tidak langsung. Pengukuran parameter perairan yang telah dilakukan dalam penelitian ini disajikan dalam Tabel 2. Lokasi penelitian ini memiliki bentuk pantai yang landai dan tidak memiliki arus dan gelombang yang tinggi seperti pada perairan Laut Selatan. Kedalaman perairan dalam penelitian ini berkisar antara 0,5 - 2 meter. Parameter lingkungan pada kedua lokasi seperti suhu, salinitas dan $\mathrm{pH}$ masih dalam kisaran yang baik jika dilihat menurut baku mutu Keputusan Menteri Lingkungan Hidup (2004). Kemudian memiliki kedalaman yang bervariasi dari tiap lokasi penelitian.

Bahan organik termasuk salah satu komponen vital bagi komunitas lamun. Karena ketersediaan bahan organik di alam dapat menjadi faktor pembatas bagi pertumbuhan lamun (Hemminga \& Duarte 2000; Barron \& Duarte 2009; Wicks et al. 2009). Hasil analisa kandungan 
bahan organik di semua Stasiun penelitian menunjukan masih baik untuk mendukung pertumbuhan lamun. Sebagaimana dijelaskan oleh Short \& Coles (2003), kandungan bahan organik dalam sedimen di daerah lamun berkisar antara 0,5-16,5\%. Kandungan bahan organik pada seluruh lokasi penelitian bisa dilihat pada Tabel 3.

Karakteristik substrat sedimen pada lokasi penelitian menunjukan hasil dari persentase sedimen dari sand, silt dan clay, sehingga dari kedua lokasi penelitian disimpulkan tidak memiliki substrat yang jauh berbeda yaitu didominansi oleh substrat sedimen pasir. Kemudian sebagian besar spesies lamun diketahui dapat tumbuh dengan baik pada sedimen berpasir dibandingkan dengan substrat berukuran besar seperti kerikil atau berukuran halus seperti lempung (Short dan Coles 2003). Dapat disimpulkan bahwa karakteristik substrat pada lokasi penelitian ini menunjang untuk pertumbuhan lamun. Substrat pada semua lokasi penelitian telah disajikan pada tabel 4

Tabel 2. Parameter Lingkungan Perairan di Lokasi Penelitian

\begin{tabular}{lcccc}
\hline \multicolumn{1}{c}{ Parameter } & $\begin{array}{c}\text { Baku } \\
\text { mutu* }^{*}\end{array}$ & Pulau Sintok & $\begin{array}{c}\text { Pulau } \\
\text { Kemujan }\end{array}$ & $\begin{array}{c}\text { Pulau Menjangan } \\
\text { Besar }\end{array}$ \\
\hline Suhu $\left({ }^{\circ} \mathrm{C}\right)$ & $28-30$ & 28 & 29 & 30 \\
Salinitas (\%) & $33-34$ & 33 & 33 & 33 \\
Derajat Keasaman $(\mathrm{pH})$ & $7-8,5$ & 7 & 7 & 7 \\
Kecerahan (\%) & - & 100 & 100 & 100 \\
Kedalaman (cm) & - & 40 & 150 & 80 \\
\hline
\end{tabular}

${ }^{*}$ Baku mutu : KepMenLH (2004)

Tabel 3. Kandungan bahan organik pada lokasi penelitian

\begin{tabular}{cc}
\hline Lokasi & Kandungan bahan organik (\%) \\
\hline Pulau Sintok & 5,63 \\
Pulau Kemujan & 4,02 \\
Pulau Menjangan Besar & 4,36 \\
\hline
\end{tabular}

Tabel 4. Substrat pada lokasi penelitian

\begin{tabular}{lccc}
\hline Substrat & Pulau Sintok & Pulau Kemujan & Pulau Menjangan Besar \\
\hline Sand (\%) & 97,4 & 87,6 & 90,6 \\
Silt (\%) & 2,1 & 9,9 & 6,9 \\
Clay (\%) & 0,53 & 2,5 & 2,5 \\
\hline
\end{tabular}

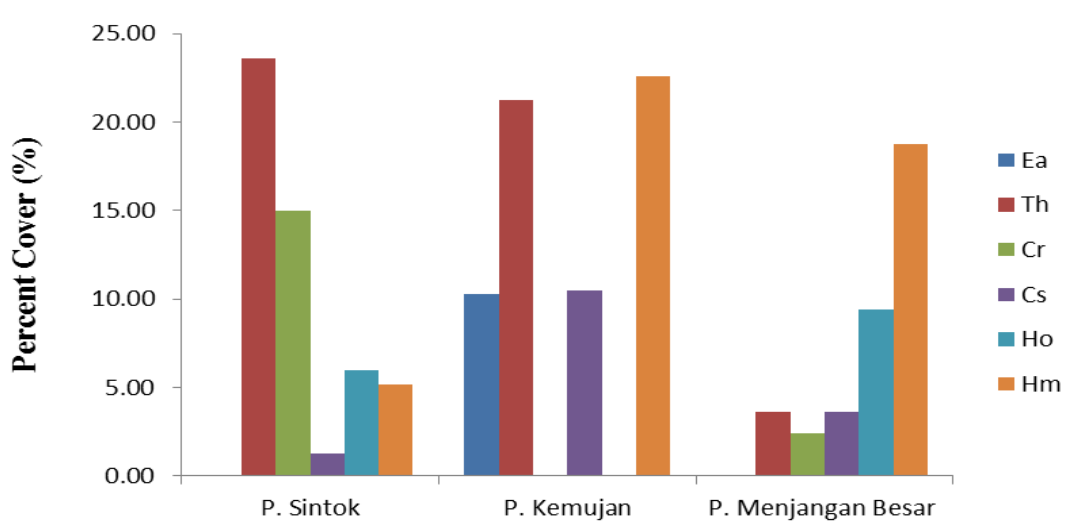

Gambar 4. Penutupan lamun pada lokasi penelitian (\%). 


\section{KESIMPULAN}

Berdasarkan hasil penelitian yang di temukan di perairan Pulau Sintok, Pulau Kemujan dan Pulau Menjangan Besar terdapat 6 jenis lamun antara lain Cymodocea serrulata, Cymodocea rotundata, Enhalus acoroides, Thallasia hemprichii, Halophila minor dan Halophila ovalis. Kerapatan lamun di Pulau Sintok,Pulau Kemujan dan Pulau Menjangan Besar memiliki kerapatan yang rendah sampai tinggi. Lamun jenis Thallasiahemprichii memiliki dominansi tertinggi pada semua lokasi penelitian, karena kerapatannya mencapai $98.22 \mathrm{ind} / \mathrm{m}^{2}$. Rata-rata tutupan lamun dari kelima stasiun pada kedua lokasi penelitian berkisar antara 1,96-23,61\%.

\section{DAFTAR PUSTAKA}

Barron, C. \& Duarte, C.M. 2009. Dissolved organic matter release in Posidonia oceanica meadow. Marine Ecology Progress Series, 374:75-84

Bengen, P.G. 2000. Sinopsis Ekosistem dan Sumberdaya Alam Pesisir. Pusat Kajian Sumberdaya Pesisir dan Lautan, Institut Pertanian Bogor

Dahuri, R. 2001. Pengelolaan Sumber Daya Wilayah Pesisir dan Lautan Secara Terpadu. PT. Pranadya Paramita, Jakarta

Departemen Kelautan dan Perikanan, 2008. Pedoman Umum Identifikasi dan Monitoring Lamun. Direktorat Konservasi dan Taman Nasional Laut. Jakarta.

Feryatun, F., Hendarto, B., \&Widyorini, N. 2012. Kerapatan dan Distribusi Lamun (Seagrass) Berdasarkan Zona Kegiatan Yang Berbeda di Perairan Pulau Pramuka, Kepulauan Seribu. Management of Aquatic Resources Journal. 1(1):44-50.

Hartati, R., Djunaedi A., Hariyadi \& Mujiyanto. 2012. Struktur Komunitas Padang Lamun di Perairan Pulau Kumbang, Kepulauan Karimunjawa. Jurnal Ilmu Kelautan. 17(4):217-225.

Hartati, R., Widianingsih, Trianto, A., Zainuri, M., \& Ambariyanto. 2017. The abundance of prospective natural food for sea cucumber Holothuria atra at Karimunjawa Island waters, Jepara, Indonesia. Biodiversitas, 18(3):947-953

Hemminga, M. \& Duarte, C.M. 2000. Seagrass Ecology. Cambridge (United Kingdom): Cambridge University Press

Kementrian Lingkungan Hidup dan Kehutanan. 2016. Statistik Balai Taman Nasional Karimunjawa. Direktorat Jenderal Konservasi dan Sumberdaya Alam dan Ekosistem. Jakarta

Kementrian Lingkungan Hidup. 2004. Tentang Kriteria Baku Kerusakan dan Pedoman Penentuan Status Padang Lamun. Keputusan Menteri Negara Lingkungan Hidup Nomor : 200. Jakarta

Mc Kenzie, Campbell, S.J. \& Roder, C.A. 2003. Seagasswatch: Manual for Mapping and Monitring Seagass Resources by Community (citizen) Volunteers. $2^{\text {nd }}$ ed. The state of Queensland, Department of Primary Industries, CRC Reef, Queensland, pp 104.

Nugraha, Y., \& Rudi, A. 2015. Teknik Identifikasi Lamun (Seagrass) di Kawasan Pulau Parang, Karimunjawa Kabupaten Jepara. Buletin Teknik Litkayasa 13(2):97-100.

Phillips, R.C. \& Menez, E. G. 1988. Seagasses. Smithsonian Contributions to the Marine Sciences. Smithsonian Institution Press, Washington, D.C.

Romimohtarto, K. dan Juwana, S. 2001. Biologi Laut Ilmu Pengetahuan Tentang Biota Laut. PT. Djambatan, Jakarta.

Short FT, Coles RG. (eds). 2003. Global Seagrass Research Methods. Elsevier Science BV. Amsterdam Waycott., M.K. McMahon., J. Mellors., A. Calladine., and D.

Sofiana, U.R., Sulardiono, B. \& Nitisupardjo, M. 2016. Hubungan Kandungan Bahan Organik Sedimen Dengan Kelimpahan Infauna Pada Kerapatan Lamun Yang Berbeda di Pantai Bandengan Jepara. Management of Aquatic Resources Journal, 5(3):135-141.

Sugiyono. 2010. Metode Penelitian Kuantitatif Kualitatif. PT. Alfabeta, Bandung.

Tomascik, T., Mah, A.J., Nontji, A, \& Moosa, M.K. 1997. The Ecology of The Indonesian Seas Part II. Periplus Editions. Singapore.

Wicks, A.F., Ingram, L.J. \& Stahl, P.D. 2009. Aggregate and organic matterdynamics in reclaimed soils as indicated by stable carbon isotopes. Soil Biology and Biochemistry, 41(2):201-209 